\title{
Response to the Comments of K. Metze and R.L. Adam on the paper "c-erbB-2 expression and nuclear pleomorphism in canine mammary tumors"
}

\author{
A.P. Dutra and G.D. Cassali \\ Laboratório de Patologia Comparada, Departamento de Patologia Geral, Instituto de Ciências \\ Biológicas, Universidade Federal de Minas Gerais, Belo Horizonte, MG, Brasil
}

\section{Correspondence}

G.D. Cassali

Laboratório de Patologia Comparada

Departamento de Patologia Geral

ICB, UFMC

Av. Antonio Carlos, 6627

31270-901 Belo Horizonte, MG

Brasil

Fax: +55-31-3499-2879

E-mail: cassalig@icb.ufmg.br
The following is our response to the comments of K. Metze and R.L. Adam (1).

The proto-oncogene c-erbB- 2 is encoded in a tyrosine kinase receptor protein that has been described in different tumors and animals. Since the initial report by Slamon et al. (2), which showed an association between amplification of this gene and poor prognosis in breast cancer, several other studies have demonstrated overexpression of c-erbB2 in about 10 to $20 \%$ of invasive breast carcinomas. The demonstration of a high percentage of c-erbB-2 overexpression in breast carcinomas suggests that it could represent an early event in breast carcinogenesis in humans (3-8) and dogs (9-11).

In our paper (12), we did not find any correlation between survival and c-erbB-2 expression or nuclear pleomorphism $(\mathrm{P}>$ $0.05)$, which is commented on by Metze and Adam (1). Really, the statistical method (Spearman rank correlation) is not the most adequate to evaluate the survival in this case as commented by Metze and Adam. However, the analysis by Kaplan-Meier plots as suggested would not be appropriate because of the small number of cases studied in our report.

\section{References}

1. Metze K \& Adam RL (2005). Comments on the paper "c-erbB-2 expression and nuclear pleomorphism in canine mammary tumors". Brazilian
Quantitative methods used in the evaluation or analysis of immunohistochemical and histological sections are very much discussed in the literature. Even imaging analysis methods do not seem to be standardized yet (1317). The Hercept Test is the FDA-approved in vitro diagnostic test marketed by DAKO. It is a semi-quantitative immunohistochemical assay used to determine overexpression of HER-2 protein in breast cancer tissue, which considers percentage of marked cells and membrane staining intensity. There are criteria for interpretation of the staining results for Her-2/neu when the HercepTest is used, but the determination of staining intensity, percentage of complete membrane and cells staining is subjective. However, in a large number of studies the reproducibility of immunohistochemical analysis of cerbB2 expression is satisfactory (18-22).

In conclusion, the main objective of our study was to demonstrate that spontaneous canine mammary tumors could be used as a model to study the mammary carcinogenic process. It is relevant to the study of human breast cancer, because we are using the same criteria and methods applied to breast cancer studies.

\footnotetext{
Journal of Medical and Biological Research, 38 165-167.

2. Slamon DJ, Clark GM, Wong SG, Levin WJ, Ulrich
} 
A \& McGuire WL (1987). Human breast cancer: correlation of relapse and survival with amplification of the Her-2 neu oncogene. Science, 253 177-182.

3. Lodato RF, Maquire HC, Grene MI, Weine DB \& Livolsi VA (1990). Immunohistochemical evaluation of c-erbB-2 oncogene expression in ductal carcinoma in situ and atypical ductal hyperplasia of the breast. Modern Pathology, 3: 449-453.

4. Alfred DC, Clark GM, Molina R, Tandon AK, Scnitt SJ, Gilchrist KW, Osborne CK, Tormey DC \& McGuire WL (1992). Overexpression of Her-2/ neu and its relationship with other prognostic factors change during the progression of in situ to invasive breast cancer. Human Pathology, 23: 974-979.

5. Bartkova J, Barnes DM, Millis RR \& Gullick WJ (1990). Immunohistochemical demonstration of c-erbB-2 protein in mammary ductal carcinoma in situ. Human Pathology, 21: 1164-1167.

6. Lilleng R, Hagmar BM \& Nesland JM (1992). CerbB-2 protein and neuroendocrine expression in intraductal carcinoma of the breast. Modern Pathology, 5: 41-47.

7. Rachamandra S, Machin L, Ashley S, Monaghan P \& Gusterson BA (1990). Immunohistochemical distribution of c-erbB-2 in in situ carcinoma: a detailed morphological analysis. Journal of $\mathrm{Pa}$ thology, 161: 7-14.

8. Schmitt FC, Figueiredo P \& Lacerda M (1995). Expression of c-erbB-2 protein and DNA ploidy in breast carcinogenesis. Archives of Pathology and Laboratory Medicine, 119: 815-820.

9. Ahern TE, Bird RC, Bird AE \& Wolfe LG (1996). Expression of the oncogene c-erbB-2 in canine mammary cancers and tumor-derived cell lines. American Journal of Veterinary Research, 57: 693696.

10. Rungsipipat A, Tateyama S, Yamaguchi R, Uchida K, Myoshi N \& Hayashi T (1999). Immunohistochemical analysis of c-yes and c-erbB-2 oncogene products and p53 tumor suppressor protein in canine mammary tumors. Journal of Veterinary and Medical Science, 61: 27-32.

11. Mulas JM, Ordás J, Millán $Y$, Fernadez-Soria $V$ \& Ramón y Cajal S (2003). Oncogene Her-2 in canine mammary gland carcinomas. Breast Cancer Research and Treatment, 80: 363-367.

12. Dutra AP, Granja NVM, Schmitt FC \& Cassali GD (2004). c-erbB-2 expression and nuclear pleomorphism in canine mammary tumors. Brazilian Journal of Medical and Biological Research, 37: 16731681.

13. Matkowsky KA, Schonfeld D \& Benya RV (2000). Quantitative immunohistochemistry by measuring cumulative signal strength using commercially available software Photoshop and Matlab. Journal of Histochemistry and Cytochemistry, 48: 300-311.

14. Sannino P \& Shousa S (1994). Demonstration of estrogen receptors in paraffin wax sections of breast carcinoma using the monoclonal antibody 1D5 and microwave oven processing. Journal of Clinical Pathology, 47: 90-92.

15. Kell DL, Kamel O \& Rouse RV (1993). Immunohistochemical analysis of breast carcinoma estrogen and progesterone receptors in paraffin-embedded tissue. Correlation of clones ER1D5 and 1A6 with cytosol-based hormone assay. Applied Immunohistochemistry, 1: 275-281.

16. Molino A, Micciolo R, Turazza M et al. (1997). Prognostic significance of estrogen receptors in 405 primary breast cancers: a comparison of immunohistochemical and biochemical methods. Breast Cancer Research and Treatment, 45: 241249.

17. Lehr HA, Mankoff DA, Corwin D, Santeusanio G \& Gown AM (1997). Application of Photoshopbased image analysis to quantification of hormone receptor expression in breast cancer. Journal of Histochemistry and Cytochemistry, 45: 15591565.

18. Rodriguez Moguel L \& Vega Ramos B (2002). Reproducibility of Her-2/neu overexpression with HERCEP test in invasive ductal breast cancer. Ginecología y Obstetricia de México, 70: 601-606.

19. Italian Network for Quality Assurance of Tumor (INQAT) Biomarkers (2004). Interobserver reproducibility of immunohistochemical HER-2/neu evaluation in human breast cancer: the real-world experience. International Journal of Biological Markers, 19: 147-154.

20. Makkink-Nombrado SV, Baak JP, Schuurmans L, Theeuwes JW \& van der Aa T (1995). Quantitative immunohistochemistry using the CAS 200/486 image analysis system in invasive breast carcinoma: a reproducibility study. Analytical Cellular Pathology, 8: 227-245.

21. Hsu CY, Ho DM, Yang CF, Lai CR, Yu IT \& Chiang $H$ (2002). Interobserver reproducibility of Her-2/ neu protein overexpression in invasive breast carcinoma using the DAKO HercepTest. American Journal of Clinical Pathology, 118: 693-698.

22. Bánkfalvi A, Simon R, Brandt B, Burger H, Vollmer I, Dockhorn-Dworniczak B, Lellé RJ \& Boecker W (2000). Comparative methodological analysis of erbB-2/HER-2 gene dosage, chromosomal copy number and protein overexpression in breast carcinoma tissues for diagnostic use. Histopathology, 37: 411-419. 